\title{
Serological markers of Bornavirus infection found in horses in Iceland
}

\author{
Sigríður Björnsdóttir ${ }^{1}$, Elfa Agustsdóttir ${ }^{2}$, Anne-Lie Blomström³ ${ }^{3}$, Inga-Lena Örde Öström ${ }^{4}$, \\ Louise Treiberg Berndtsson ${ }^{4}$, Vilhjálmur Svansson ${ }^{5}$ and Jonas Johansson Wensman ${ }^{3,6^{*}}$
}

\begin{abstract}
Background: In a stable of eight horses in Northern Iceland, six horses presented with clinical signs, such as ataxia and reduced appetite, leading to euthanasia of one severely affected horse. Serological investigations revealed no evidence of active equine herpes virus type 1 infection, a common source of central nervous system disease in horses, nor equine arteritis virus and West Nile virus. Another neurotropic virus, Borna disease virus, was therefore included in the differential diagnosis list.

Findings: Serological investigations revealed antibodies against Borna disease virus in four of five horses with neurological signs in the affected stable. One horse without clinical signs was seronegative. Four clinically healthy horses in the stable that arrived and were sampled one year after the outbreak were found seronegative, whereas one of four investigated healthy horses in an unaffected stable was seropositive.

Conclusions: This report contains the first evidence of antibodies to Borna disease virus in Iceland. Whether Borna disease virus was the cause of the neurological signs could however not be confirmed by pathology or molecular detection of the virus. As Iceland has very restricted legislation regarding animal imports, the questions of how this virus has entered the country and to what extent markers of Bornavirus infection can be found in humans and animals in Iceland remain to be answered.
\end{abstract}

Keywords: Borna disease, Neurological disease, Serology, Epidemiology, Horse

\section{Findings}

Borna disease virus (BDV) is a negative-stranded RNAvirus infecting and causing neurological disease in several warm-blooded animals $[1,2]$. The clinical signs in horses usually start with disturbances in feed intake, fever and various degrees of somnolence. Later, ataxia, and other gait disturbances, more severe somnolence and finally paralysis of extremities and head develop (reviewed in [2]). Other mental changes are also common, such as depression, coma and excitations. The virus transmission routes are still obscure, but the involvement of reservoir hosts, such as wild birds, rodents and insectivores, has been proposed [1,3-5]. Most cases of equine Borna disease (BD) have been reported from Central Europe; however, BDV-

\footnotetext{
* Correspondence: Jonas.Wensman@slu.se

${ }^{3}$ Department of Biomedical Sciences and Veterinary Public Health, Swedish University of Agricultural Sciences, P.O. Box 7028, SE-750 07 Uppsala, Sweden ${ }^{6}$ Department of Clinical Sciences, Swedish University of Agricultural Sciences, P.O. Box 7054, SE-750 07 Uppsala, Sweden

Full list of author information is available at the end of the article
}

infection markers have been reported all over the world [1]. Avian Bornavirus (ABV) was recently found to cause proventricular dilatation disease in psittacine and other avian species, increasing the host spectrum and spread of these intriguing viruses [1-3].

Here, we describe the first evidence of antibodies to BDV in Iceland, detected in an outbreak of neurological disease in horses.

In a geographically isolated fishing village in northern Iceland there is a cluster of twelve stables that house about 70-80 horses during the winter. In February 2011, one of the stables (stable A) with 8 horses reported neurological signs in horses (for details see Table 1). The clinical signs started in a 21-year-old gelding (horse no. 1) that presented with pelvic limb ataxia and reduced appetite. Normal body temperature and full consciousness was recorded at first day of clinical signs (day 0 ) in this horse. After 3-4 days of treatment (Table 1), the horse (no. 1) improved temporarily; however, after another week it developed more severe ataxia and loss of appetite, finally

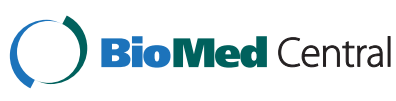

(c) 2013 Björnsdóttir et al.; licensee BioMed Central Ltd. This is an open access article distributed under the terms of the Creative Commons Attribution License (http://creativecommons.org/licenses/by/2.0), which permits unrestricted use, distribution, and reproduction in any medium, provided the original work is properly cited. 
Table 1 Clinical signs and history of horses in the affected stable (stable A)

\begin{tabular}{|c|c|c|c|c|}
\hline Horse ID/age & Day 0 & Day 7 & Day 14 & Day 21 \\
\hline 1. & Ataxia and reduced appetite & Temporary improvements & Severe ataxia/paralysis and loss of appetite & Euthanized \\
\hline 21 y & Treatment $1^{\mathrm{a}}$ at day 4 & & Treatment $2^{\mathrm{b}}$ & \\
\hline $2 .^{c}$ & No clinical signs & No clinical signs & Ataxia, depression and reduced appetite & Slow recovery \\
\hline $21 y$ & & & Treatment $2^{\mathrm{b}}$ & \\
\hline 3. & No clinical signs & No clinical signs & Ataxia, mild excitation and reduced appetite & Slow recovery \\
\hline $12 y$ & & & Treatment $2^{\mathrm{b}}$ & \\
\hline 4. & No clinical signs & No clinical signs & Ataxia, mild excitation and reduced appetite & Slow recovery \\
\hline $18 y$ & & & Treatment $2^{\mathrm{b}}$ & \\
\hline 5. & No clinical signs & No clinical signs & Mild signs of ataxia and excitation & Recovery \\
\hline $13 y$ & & & Treatment $2^{\mathrm{b}}$ & \\
\hline 6. & No clinical signs & No clinical signs & Mild signs of ataxia & Recovery \\
\hline $6 y$ & & & Treatment $2^{\mathrm{b}}$ & \\
\hline 7. & No clinical signs & No clinical signs & No clear signs & Recovery \\
\hline $9 y$ & & & Treatment $2^{\mathrm{b}}$ & \\
\hline 8. & $\begin{array}{l}\text { Arrived to the stable } 10 \text { days earlier. } \\
\text { No clinical signs }\end{array}$ & No clinical signs & No clinical signs & No clinical signs \\
\hline
\end{tabular}

${ }^{a}$ Treatment 1 is dexamethasone $20 \mathrm{mg} /$ day for 6 days i.m., procaine benzyl penicillin $4000 \mathrm{mg} /$ day for 6 days i.m.

${ }^{b}$ Treatment 2 is oxytetracycline $4000 \mathrm{mg}$ i.v. once, glucose $30 \% 1000 \mathrm{ml}$ i.v. once, metamizole $1500 \mathrm{mg}$ i.v. once, dexamethasone $20 \mathrm{mg} /$ day i.m. daily for 8 days, ampicillin $1.67 \mathrm{~g}$ /day i.m. daily for 6 days, with additional support: medical coal p.o. daily for 8 days, Prolac AB p.o. daily for 6 days, Pro-Bran (Protexin, Probiotics, Somerset, UK) p.o. daily for 12 days, Ferro Complex (Blue Hors, Randbøl, Denmark) p.o. for 1 month.

'This horse was euthanized approx. 6 months after the onset of signs, because of age and a history of intermittent lameness, most likely independent of the neurological signs.

becoming paralysed in its pelvic limbs and was euthanized (day 21). At this time-point (day 13-14), five other horses (horses no. 2-6) were also affected, showing various degrees of pelvic limb ataxia, depression or excitation and reduced appetite (Table 1). The body temperature of all horses was found to be within the normal range. As the horses were examined under field conditions, a detailed neurological status was, however, not achieved. All horses, except for one mare (horse no. 8) that showed no clinical signs and had arrived 10 days before the time of onset of clinical signs in horse no. 1 (day -10), were treated as indicated in Table 1 . Horses no. 5-6 recovered by day 21, while horses no. $2-4$ had a slow recovery and were only fully recovered around 3 months after onset of signs in the index case. Horse no. 2 was euthanized approximately 6 months after onset of signs due to age and a history of intermittent lameness, most likely independent of the neurological signs. Horse no. 8 did not show any clinical signs throughout the whole observation period (until day 440).

Initially, serum samples from four of the horses (horses no. 2, 3, 5 and 6) were taken for serological analyses 9-10 days after they presented with neurological signs and three weeks after onset of signs in the index case (day 23). No antibodies towards equine herpes virus (EHV) types 1 and 4 were found by complement fixation. Presence of IgGantibodies against EHV-1 detected by ELISA (Svanovir EHV1/EHV4-Ab, Svanova, Uppsala, Sweden) in one horse (no. 5) was not regarded to indicate an active EHV-1 infection and none of the other investigated horses in the outbreak stable had this finding in the observation period (from day 23 to 440). Antibodies to equine arteritis virus (EAV) and West Nile virus (WNV) were not detected by serum neutralization test and ELISA (ID Screen West Nile Competition, ID-vet, Montpellier, France), respectively. Infection with an alphavirus was considered unlikely based on the clinical signs and epidemiology. We therefore decided to include BDV as a differential diagnosis.

An indirect immunofluorescence assay (IFA) was employed as previously described [6], except for the use of fluorescein isothiocyanate (FITC) conjugated anti-horse IgG antibodies as secondary antibodies. Horse sera previously characterised as positive or negative for BDV antibodies in a BDV-ELISA were used as controls, whereof one of the positive controls also was PCR-positive and positive at Western blotting [7]. Serum incubation on slides with non-infected cells was used as negative controls, to exclude the possibility for unspecific fluorescence signals due to cross-reactivity. All serum samples were sent for a second IFA analysis [8] (Idexx/Vet Med Labor, Ludwigsburg, Germany). An individual sample was considered seropositive if a titre of $\geq 1: 40$ was detected in both IFAs, negative if both titres were $<1: 40$, and doubtful if only one of the IFAs showed a titre of $\geq 1: 40$.

Around 10 days after onset of clinical signs, all horses showing clinical signs (horses no. 2-5) were positive in the first IFA, and two of the horses (horses no. 2 and 5) 
Table 2 BDV serology of horses in the affected stable A

\begin{tabular}{|c|c|c|c|c|}
\hline Horse ID & Clinical signs $^{\mathrm{a}}$ (see Table 1 ) & Day $23\left(\right.$ IFA $1^{b} /$ IFA2 $^{\mathrm{c}}$ ) & Approx. day 380 (IFA1 ${ }^{\mathrm{b}} / \mathrm{IFA} 2^{\mathrm{C}}$ ) & Approx. day $440\left(\mathrm{IFA} 1^{\mathrm{b}} / \mathrm{IFA} 2^{\mathrm{c}}\right)^{\mathrm{d}}$ \\
\hline 1. & ++++ & n.d. ${ }^{e}$ & n.d. & n.d. \\
\hline 2. & ++++ & $1: 160 / 1: 80$ & n.d. & n.d. \\
\hline 3. & ++ & $1: 80 /<1: 10$ & $1: 40 /<1: 10$ & $1: 160 / 1: 40$ \\
\hline 4. & ++ & n.d. & n.d. & $<1: 20 / 1: 40$ \\
\hline 5. & + & $1: 160 / 1: 40$ & $1: 320 /<1: 10$ & $1: 160 /<1: 10$ \\
\hline 6. & + & $1: 80 /<1: 10$ & $1: 160 / 1: 40$ & n.d. \\
\hline 7. & $(+)$ & n.d. & n.d. & $1: 160 / 1: 40$ \\
\hline 8. & - & n.d. & n.d. & $<1: 20 /<1: 10$ \\
\hline
\end{tabular}

${ }^{a}$ The degree of clinical signs is indicated as $++++=$ severe clinical signs, $++=$ moderate signs, $+=$ mild signs, and $(+)=$ no clear signs.

bIFA1 is the IFA performed in Sweden.

IFA2 is the IFA performed in Germany.

dSamples were blindly tested.

en.d. indicates not done.

were positive by the second IFA, and thus defined seropositive (Table 2). These results led to an increased monitoring of the horses in the affected stable (Tables 2 and 3). Blood and serum samples were collected 380440 days after the outbreak from 3 of the 4 horses initially tested. Additionally, blood samples were collected from 6 other horses in stable A. Three of these 6 horses had been in the stable at the time of the outbreak (Tables 2 and 3). The horses were either seropositive (no. 2, 3, 5-7) or doubtful seropositive (no. 4) for BDV-antibodies (Table 2). No BDV-specific antibodies were detected in horse no. 8 that arrived to the stable at day -10 , indicating that BDV entered the stable before that time. This horse showed no clinical signs throughout the observation period (until day 440). Likewise, all horses, that were housed in stable A in 2012 but not in 2011, did not show any signs of neurological disease and were seronegative (Table 3). As comparison, horses in another stable (stable B) with no evidence of neurological disease, situated approximately $50 \mathrm{~km}$ southwest of the affected stable, were investigated. In stable B one horse had presence of BDVspecific antibodies, one was seronegative and two were

Table 3 BDV serology of clinically healthy horses

\begin{tabular}{|c|c|}
\hline Horse ID/Stable ID & IFA $1^{\mathrm{a}} / \mathrm{IFA} 2^{\mathrm{b}}$ \\
\hline $9 . / \mathrm{A}-12$ & $<1: 20 /<1: 10$ \\
\hline 10. / A-12 & $<1: 20 /<1: 10$ \\
\hline 11. / A-12 & $<1: 20 /<1: 10$ \\
\hline $12^{\mathrm{C}} / \mathrm{B}$ & $1: 160 /<1: 10$ \\
\hline $13^{c} / B$ & $<1: 20 /<1: 10$ \\
\hline $14 .^{c / B}$ & 1:160/1:160 \\
\hline $15^{c} / \mathrm{B}$ & $1: 40 /<1: 10$ \\
\hline
\end{tabular}

IFA1 is the IFA performed in Sweden.

${ }^{\mathrm{b}} \mathrm{IFA} 2$ is the IFA performed in Germany.

'Samples were blindly tested.

A-12 refers to horses that entered the affected stable the year after the outbreak (2012). Stable B is situated ca. $50 \mathrm{~km}$ southwest of stable A. The two stables have had no contacts. considered doubtful (Table 3). There were no contacts between stables A and B.

Molecular diagnostics was performed using previously described real-time and conventional RT-PCR assays targeting three genes of BDV (P, N and M) $[6,9,10]$. Total RNA was extracted from peripheral blood drawn at day 380 from horses no. 3, 5 and 6 as previously described [6]; however, we could not confirm presence of BDV-RNA in any of the horses.

The euthanized horses were not sent for necropsy; thus, there are no pathology data confirming inflammatory changes of the central nervous system indicating virus infection. Nevertheless, this report shows the first evidence of antibodies to BDV in Iceland, a country with extremely strict animal import regulations, indicating that these horses have been exposed to BDV or a closely related virus. In 1998, we conducted a study of 17 Icelandic horses with pyrexia of unknown reason, which found all to be seronegative by BDV-ELISA (performed at Robert Koch Institute, Berlin, Germany). How the virus has entered Iceland remains to be determined. One possible route of transmission is by migratory birds, because wild birds have been indicated as potential reservoirs of BDV [1,3]. A unique strain of Bornavirus was recently found in healthy Canada geese in the USA, indicating that this migrating waterfowl could carry virus over long distances [11]. Around 60 species of migrating birds visit Iceland during April to October. Many of them pass North Iceland, including swans, geese and loons. The Canada goose is recognised as an annual visitor in spring and autumn, originating both from Europe and North America [12]. Because of the extremely rigid animal import regulations of Iceland, migratory birds are more likely routes of Bornavirus transmission, than domestic animal transports. It has also been proposed that horses in stables along the paths of migratory birds have higher seroprevalence than horses in areas absent of migratory birds [13]. As antibodies to both BDV and ABV crossreact with the strain $(\mathrm{He} / 80)$ used in the IFAs in our study 
[14], we cannot exclude that the virus circulating in Iceland could be ABV or a more avian-like Bornavirus.

In conclusion, we present the first evidence of antibodies to Bornavirus in Iceland, found in horses with and without neurological signs. The aetiology of the neurological signs has not been confirmed, and other causes, such as toxins or other viruses, cannot be excluded. Acquired equine polyneuropathy has recently been described in Swedish, Norwegian and Finnish horses, but this syndrome does not give rise to ataxia [15]. Hence, it seems unlikely that the horses in this study suffered from this syndrome. The questions of how Bornavirus has entered the country and to what extent markers of Bornavirus infection can be found in humans and animals in Iceland remain to be answered.

\section{Abbreviations \\ ABV: Avian Bornavirus; BD: Borna disease; BDV: Borna disease virus; EAV: Equine arteritis virus; EHV: Equine herpes virus; ELISA: Enzyme-linked immunosorbent assay; FITC: Fluorescein isothiocyanate; IFA: Immunofluorescence assay; IgG: Immunoglobulin G; RT-PCR: Reverse transcription polymerase chain reaction; WNV: West Nile virus.}

\section{Competing interests}

The authors declare that they have no competing interests.

\section{Authors' contributions}

SB conceived and designed the study, performed sampling, clinical evaluation, interpreted the data and helped to draft the manuscript. EA performed sampling, clinical examinations and treatment. ALB performed molecular diagnostics and helped to draft the manuscript. ILÖ performed and analysed serological assays. LTB participated in the conception and design of the study, and helped to draft the manuscript. VS conceived and designed the study, interpreted the data, and helped to draft the manuscript. JJW conceived, designed and coordinated the study, performed and analysed serological assays, interpreted the data and drafted the manuscript. All authors approved the final manuscript.

\section{Acknowledgements}

The authors would like to acknowledge Linda Forslund and Lena Renström (National Veterinary Institute, Sweden) for assistance with the serology. Financial support from the Swedish Foundation of Equine Research (H0747211) and the Companion Animal Research Foundation of the Swedish University of Agricultural Sciences is greatly acknowledged.

\footnotetext{
Author details

${ }^{1}$ Icelandic Food and Veterinary Authority, Austurvegur 64, IS-800 Selfoss, Iceland. ${ }^{2}$ Logmannshild Veterinary Clinic, IS-603 Akureyri, Iceland. ${ }^{3}$ Department of Biomedical Sciences and Veterinary Public Health, Swedish University of Agricultural Sciences, P.O. Box 7028, SE-750 07 Uppsala, Sweden. ${ }^{4}$ Department of Virology, Immunobiology and Parasitology, National Veterinary Institute, SE-751 89 Uppsala, Sweden. ${ }^{5}$ Institute for Experimental Pathology, University of Iceland, Keldur, IS-112 Reykjavik, Iceland. ${ }^{6}$ Department of Clinical Sciences, Swedish University of Agricultural Sciences, P.O. Box 7054, SE-750 07 Uppsala, Sweden.
}

Received: 10 April 2013 Accepted: 21 October 2013 Published: 1 November 2013

\section{References}

1. Kinnunen PM, Palva A, Vaheri A, Vapalahti O: Epidemiology and host spectrum of Borna disease virus infections. J Gen Virol 2013, 94:247-262.

2. Wensman JJ: Borna disease virus and its hosts. Vet Sci Tomorrow 2012, 12. http://www.vetscite.org/publish/articles/000106/print.html.

3. Payne SL, Delnatte P, Guo J, Heatley JJ, Tizard I, Smith DA: Birds and Bornaviruses. Anim Health Res Rev 2012, 13:145-156.
4. Berg M, Johansson M, Montell H, Berg AL: Wild birds as a possible natural reservoir of Borna disease virus. Epidemiol Inf 2001, 127:173-178.

5. Hilbe M, Herrsche R, Kolodziejek J, Nowotny N, Zlinsky K, Ehrensperger F: Shrews as reservoir hosts of Borna disease virus. Emerg Inf Dis 2006, 12:675-677.

6. Wensman JJ, Jäderlund KH, Gustavsson MH, Hansson-Hamlin H, Karlstam E, Lilliehöök I, Öström IL, Belák S, Berg M, Holst BS: Markers of Borna disease virus infection in cats with staggering disease. J Feline Med Surg 2012, 14:573-582.

7. Berg AL, Dörries R, Berg M: Borna disease virus infection in racing horses with behavioral and movement disorders. Arch Virol 1999, 144:547-559.

8. Rott R, Herzog S, Fleischer B, Winokur A, Amsterdam J, Dyson W, Koprowski $\mathrm{H}$ : Detection of serum antibodies to Borna disease virus in patients with psychiatric disorders. Science 1985, 228:755-756.

9. Weissenböck H, Sekulin K, Bakonyi T, Hogler S, Nowotny N: Novel avian Bornavirus in a nonpsittacine species (Canary; Serinus canaria) with enteric ganglioneuritis and encephalitis. J Virol 2009, 83:11367-11371.

10. Wensman JJ, Thorén $\mathrm{P}$, Hakhverdyan M, Belák S, Berg M: Development of a real-time RT-PCR assay for improved detection of Borna disease virus. J Virol Methods 2007, 143:1-10.

11. Payne S, Covaleda L, Jianhua G, Swafford S, Baroch J, Ferro PJ, Lupiani B, Heatley J, Tizard I: Detection and characterization of a distinct Bornavirus lineage from healthy Canada geese (Branta canadensis). J Virol 2011, 85:12053-12056.

12. Hilmarsson JÓ: Icelandic Bird Guide. Mál og menning: Reykjavik; 2011.

13. Teplitsky V, Pitlik S, Richt JA, Herzog S, Meir R, Marcus S, Sulkes J, Weisman $Y$, Malkinson M: Increased prevalence of Borna disease virus ELISA and immunofluorescent antibodies in horses from farms situated along the paths of migratory birds. Israel J Vet Med 2003, 58:80-85.

14. Herzog S, Enderlein D, Heffels-Redmann U, Piepenbring A, Neumann D, Kaleta EF, Müller H, Lierz M, Herden C: Indirect immunofluorescence assay for intra vitam diagnosis of avian Bornavirus infection in psittacine birds. J Clin Microbiol 2010, 48:2282-2284.

15. Gröndahl G, Hanche-Olsen S, Bröjer J, Ihler CF, Jäderlund KH, Egenvall A: Acquired equine polyneuropathy in Norway and Sweden: a clinical and epidemiological study. Equine Vet J 2012, 44(Suppl 43):36-44.

doi:10.1186/1751-0147-55-77

Cite this article as: Björnsdóttir et al:: Serological markers of Bornavirus infection found in horses in Iceland. Acta Veterinaria Scandinavica $201355: 77$

\section{Submit your next manuscript to BioMed Central and take full advantage of:}

- Convenient online submission

- Thorough peer review

- No space constraints or color figure charges

- Immediate publication on acceptance

- Inclusion in PubMed, CAS, Scopus and Google Scholar

- Research which is freely available for redistribution 